\title{
Pengaruh Corporate Governance Terhadap Kinerja Keuangan Perusahaan Sektor Trade, Service And Investmen
}

\author{
Eko Prasetio ${ }^{1}$, Risal Rinova ${ }^{2}$ \\ ${ }^{1,2}$ Universitas Sarjanawiyata Tamansiswa \\ ekoprasetio656@gmail.com,
}

Received 05 Februari 2021| Revised 05 Maret 2021 | Accepted 05 Maret 2021

*Korespondensi Penulis

\begin{abstract}
Abstrak
Fokus kajian dalam penulisan ini adalah corporate governance. Corporate governance berfungsi sebagai mekanisme pemantuan pada perusahaan yang timbul akibat adanya konflik kepentingan antara pemegang saham dan manajemen perusahaan. Adapun tujuan penelitian ini ialah untuk menguji dan menganalisis pengaruh corporate governance terhadap kinerja keuangan perusahaan sektor trade, service and investmen yang terdaftar di IDX priode 2014-2018. Penelitian ini menggunakan teknik purposive sampling dengan sempel 23 perusahaan. Analisis ini menggunakan pengujian statistic dengan bantuan program SPSS21. Pengujian hipotesis menggunakan uji t. dari hasil penelitian, didapatkan variabel yang tidak berpengaruh signifikan terhadap kinerja keuangan, yaitu ukuran dewan direksi dan frekuensi rapat dewan direksi. Sedangkan proporsi dewan komisaris independen berpengaruh negative dan signifikan terhadap kinerja keuangan. Namun komite audit memiliki pengaruh positif dan signifikan terhadap kinerja keuangan. Dengan demikian, penelitian ini menyarankan kepada perusahaan untuk meningkatkan mekanisme corporate governance guna memaksimalkan kinerja keuangan perusahaa.
\end{abstract}

Kata kunci: Corporate governance; Kinerja keuangan; sector trade; service and investmen.

\begin{abstract}
The focus of the study in this paper is corporate governance. Corporate governance functions as a monitoring mechanism in a company that arises from a conflict of interest between shareholders and company management. The purpose of this study is to examine and analyze the influence of corporate governance on the financial performance of trade, service and investmen companies listed on IDX for the period 2014-2018. This study uses purposive sampling technique with a sample of 23 companies. This analysis uses statistical testing whith the help of the SPSS21 program. Hypothesis testing using $t$ test. From the research results, it is found that the variables that do not have a significant effect on financial performance are the size of the board of directors and the frequency of board meetings. Meanwhile, the proportion of independent commissioners has a negative and significant effect on financial performance. However, the audit committee has a positive and significant effect on financial performance. Thus, this study suggests companies to improve their corporate governance mechanisms in oder to maximize their financial performance.
\end{abstract}

Keywords: Corporate Governance; Financial Performance; Sektor Trade; Service and Investment.

\section{PENDAHULUAN}

Perusahaan adalah setiap bentuk usaha yang melakukan kegiatan secara tetap dan terus menerus dengan tujuan memperoleh keuntunagn dan atau laba, baik yang diselenggarakan oleh orangperorangan maupun badan usaha yang berbentuk badan hukun atau bukan badan hukum, yang didirikan dan 
kedudukan dalam wilayah Negara Republik Indonesia (Undang-undang No.8 pasal 1ayat, tahun 1997 tentang dokumen perusahan). Adapun pihak perusahaan yang berperan penting dalam proses oprasional perusahaan ialah manajer, chief executive officers (CEO), pemegang saham dan direktur (Hong et al., 2016). Atas dasar timbulnya kepentingan tersebut maka perlu adanya corporate governance yang baik sebagai mekanisme monitoring terhadap kinerja keuangan perusahaan.

Index sector trade, service and investmen sebagai indexs yang mencerminkan seluruh saham yang terdapat di sector trade, service and investmen yang tercatat di IDX pun mel-listing di perusahaanperusahaan yang menggunakan good corporate governance (GCG). Namun penelitian mengenai corporate governance dan kinerja keuangan pada seluruh saham yang listing di index sector trade, service and investment masih jarang dilakukan. Begitu pula kinerja keuangan tercermin melalui good corporate governance. Penelitian (Sigalingging \& Dewi, 2019) tentang pengaruh deviden dan ukuran perusahaan terhadap leverage perusahaan dengan investmen opportunity set (IOS) sebagai variabel moderasi pada sector trades, services and investmen yang terdaftar di BEI. Penelitian (Togatorop et al., 2019) tentang pengaruh leverage (DER),(ROA),(CR) trhadap harga saham pada sector trade, service and investmen yang terdaftar di BEI. (Ginting et al., 2020) tentang factor-faktor yang mempengaruhi kebijakan deviden pada sector trade, service and investmen yang terdaftar di BEI.

Kinerja keuangan merupakan patokan utama untuk mengukur baik atau tidaknya kinerja keuangan perusahaan, hal tersebut dapat dilihat dari laoparan keuangan (Salsabila Sarafina, 2017). Peranan prinsip-prinsip good corporate governance dapat berkontribusi dalam peningkatatan kinerja perusahaan (Muhammad Rizky Afinurzaid, 2019). Penelitian (Salsabila Sarafina, 2017) melakukan penelitian untuk mengatahui good corporate governance terhadap kinerja keuangan dan nilai perusahaan, dimana corporate governance diproksikan dengan proporsi dewan kimisaris independen dan komite audit. Penelitian (Setiawan, 2016) memproksikan corporate governance dengan komposisi dewan komisaris independen, jumlah dewan direksi, dan kepemilikan institusional terhadap kinerja keuangan perusahaan. Penelitian (Hendratni, 2018) memproksikan corporate governance dengan dewan komisaris, direksi, kepemilikan institusional, dan komisaris independen terhadap kinerja keuangan perusahaan perbankan yang terdaftar di BEI. Sedangkan corporate governance dalam penelitian ini diproksikan dalam proporsi dewan komisaris indepanden, komite audit, ukuran dewan direksi, dan frekuensi rapat dewan direksi terhadap kinierja keuangan perusahaan.

Adapun yang menjadi permasalahan dalam penelitian ini adalah apakah corporate governance yang di proksikan dengan proporsi dewan komisaris independen,komie audit,ukuran dewan dirieksi, dan frekuensi rapat dewan direksi secara parsial berpengaruh terhadap kinerja keuangan perusahaan pada sector trade service and investmen yang terdaftar di IDX priode 2014-2018. Tujuan dari penelitian ini adalah untuk mengkaji dan menganalisis corporate governance yang diproksikan dengan proporsidewan komisaris independen, komite audit, ukuran dewan direksi dan frekuensi rapat dewan dieksi terhadap kinerja keuangan perusahaan sector trade, service and investmen priode 2014-2018.

Melihat pentingnya corporate governance untuk banyak pihak, baik itu perusahaan, pemegang saham, masyarakat dan Negara maka perusahaan wajib mengelola dan menerapkan good corporate governance (GCG). Hal ini sesuai dengan peraturan yang telah ditetapkan oleh mentri BUMN tentang penerapan good corporate governance (GCG) (BUMN, 2011). Melihat rendahnya tingkat penelitian corporate governance terhadap kinerja keuangan perusahaan pada sector trade, service and investmen, oleh karena itu peneliti tertarik meneliti hubungan corporate governance terhadap kinerja keuangan perusahaan pada sector trade, service and investmen yang terdaftar di IDX pada priode 2014-2018.

\section{Teori Keagenan}

Teori keagenan atau agency theory adalh yang menggambarkan hubungan antara pemegang saham (principal) dan manajer (agen) (Muhammad Rizky Afinurzaid, 2019). Jensen dan Meckling (1976) berpendapat bahwa hubungan keagenan muncul ketika satu atau lebih individu (principal) mempekerjakan individu lain (agen) untuk menyediakan suatu jasa dan kemudian mendelegasikan wewenang pengambilkeputusan kepada agen tersebut. Teori keagenan juga menjadi dasar penerapan corporate governance, sehingga dapat memberikan keyakinan pada principal bahwa mereka akan menerma return atas investasi mereka (Muhammad Rizky Afinurzaid, 2019). 


\section{Kerangka Pikir}

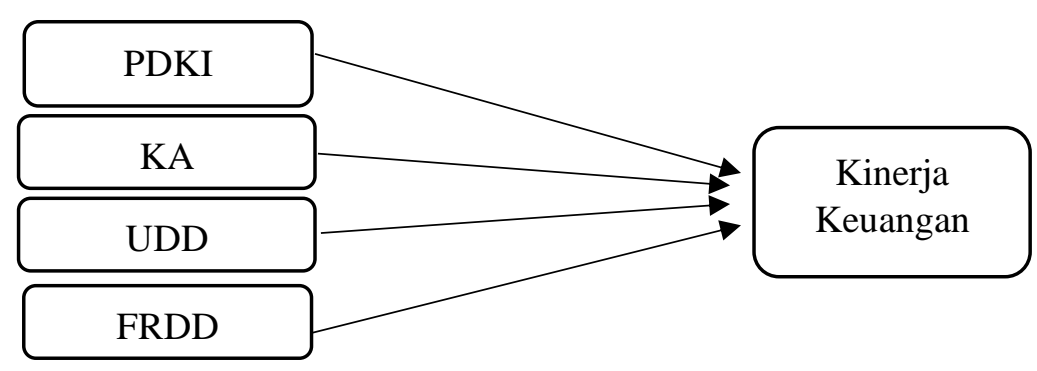

Gambar 1. Kerangka Pikir

\section{Hipotesis}

Berdasarkan penelitian (Mulyadi, 2016) hasil penelitiannya proporsi dewan komisaris independen berpengaruh signifikan terhadap kinerja keuangan perusahaan. Penelitian (Azis \& Hartono, 2017) menunjukan bahwa secara simultan ukuran dewan komisaris independen secara positif dan signifikan mempengaruhi kinerja keuangan perusahaan. Penelitian (Hendratni, 2018) menunjukan bahwa secara simultan ukuran dewan komisaris independen berpengaruh positif terhadp kinerja keuangan perusahaan. Penelitian (Muhammad Rizky Afinurzaid, 2019) menunjukan bahwa komisaris independen berpengaruh positif terhadap nilai perusahaan. Penelitaian (Agatha et al., 2020) menunjukan bahwa dewan komisaris independen memiliki pengaruh positif dan signifikan terhadap kinerja keuangan perusahaan. Penelitian (Kusnadi, 2018) menunjukan bahwa proporsi dewan komisaris independen memiliki pengaruh positif dan signifikan terhadap kinerja perusahan. Penelitian (Saifi, 2019) menunjukan bahwa proporsi dewan komisaris independen berpengaruh positif dan signifikan terhadap kinerja keuangan perusahaan di ukur dengan ROA. Penelitian ini sejalan dengan penelitian (Salsabila Sarafina, 2017) dan (EVIYANAH, 2018) bahwa proporsi dewan komisaris independen berpengaruh positif terhadap kinerja keuangan perusahaan. Berdasarkan hasil penelitian terdahulu, hipotesis yang di ambil yaitu :

H1: proporsi dewan komisaris indeoenden berpengaruh positif dan signifikan terhadap kinerja keuangan perusahaan sector trade, service and investmen

Komite audit merupakan variabel independen yang bertujuan untuk melaksanakan pengawasan cecara independen atas proses corporate governance (Governance, 2016). Hasil penelitian (Abdulazeez DA, 2016) komite audit berpengaruh positif tetapi tidak signifikan terhadap kierja bank. Penelitan (Atmaja et al., 2015) menunjuakan bahwa komite audit berpengaruh positif dan signifikan terhadap cash flow return on asset. Penelitian (Widianingsih, 2018) menunjukan bahwa komite audit berpengaruh positif dan signifikan terhadap niali perusahaan. Penelitian (Salsabila Sarafina, 2017) menunjukan bahwa komite audit berpengaruh terhadap kinerja keuangan perusahaan. Penelitan (Agatha et al., 2020) menunjukan bahwa komite audit berpengaruh positif dan signifikan terhadap kinerja keuangan perusahaan. Penelitian (Cabrera Marino, 2017) menunjukan bahwa komite audit memiliki pengaruh yang signifikan terhadap kinerja keuangan perusahaan. Penelitian (Nurhidayah, 2020) meunjukan bahwa komite audit dapat meningkatkan kinerja keuangan perusahaan. Penelitian (Kusnadi, 2018) menunjukan bahwa komita audit berpengaruh positif tetapi tidak signifikan terhadap kinerja keuangan peusahaan. Penelitian (Yunina \& Nisa, 2019) menunjukan koite audit berpengaruh positif dan signifikan terhadap kinerja keuangan perusahaan. Dari hasil penelitian terdahulu, dalam penelitian ini dapat diambil hipotesis sebagai berikut:

H2: komite audit berpengaruh positif dan signifikan terhadap kinerja keuangan perusahaan sector trade, service and investmen

Dewan direksi sebagai organ perusahaan bertugas dan bertanggungjawab secara koligeal dalam pengolahan perusahaan. Oleh karena itu ukuran dewan direksi merupakan hal penting dalam mentukan arah dan menjalankan perusahaan untuk mencapai kinerja perusahaan yang baik. Penelitian (Mohammed, 2020) menunjukan bahwa ukuran dewan direksi berpengaruh positif signifikan terhadap kinerja keuangan perusahaan. Penelitan (Atmaja et al., 2015) meneunjukan bahwa dewan direksi berpengaruh positif signifikan terhadap chas flow retrun on asset. Peelitian (Indahningrum, 2020) menunjukan bahwa ukuran dewan diresksi memiliki hubungan positif terhadap frim value melalui 
corporate environmental disclosure. Penelitian (Prayanthi \& Laurens, 2020) menunjukan bahwa ukran dewan direksi memiliki pengaruh positif dan signifikan terhadap retrun on equity. Penelitain (Dhea Gitami Fintreswari, 2017) menunjukan bahwa ukuran dewan direksi memiliki pengaruh positif dan signifikan terhadap nilai perusahaan. Penelitian (Eksandy, 2018) menunjukan bahwa dewan direksi berpengaruh positif dan signifikan terhadap kinerja keuangan perusahaan. Penelitain (EVIYANAH, 2018) menunukan ukuran dewan direksi memiliki pengaruh positif terhadap kinerja keuangan perusahaan. Penelitian ini sejalan dengan penelitian (Abdulazeez DA, 2016) menunjukanbahwa ukuran dewan direksi berpengaruh positif terhadap kinerja keuangan perusahaan. Dari hasil penelitian terdahulu, dalam pennelitian ini dapat di ambil hipotesis :

H3: ukuran dewan direksi berpengaruh positif dan signifikan terhadp kinerja keuangan perusahaan sector trade, service and investmen

Frekuensi rapat dawan di yakini mempengaruhi kinerja keuagnan perusahaan (Jensen, 1993). Dalam rapat dewan meliliki bayak waktu untuk bertukar, berdiskusi, dan berbagi ide, merencanakan strategi untuk perusahaan untuk menyeleaikan masalah besar perusahaan serta menentukan arah dan oprasional perusahaan. Hasil penelitain (Mohammed, 2020) menunjukan bahwa frekuensi rapat deewan direkisi berpengaruh positif signifikan terhadap kinerja keuangan perusahaan. Sedangkan (U. B. Azubike et al., 2015) menunjukan rapat dewan direksi berdampak signifikan terhadap laba perusahaan. Penelitian (PUTRI, 2018) menunjukan bahwa frekuensi rapat dewan direksi mempengaruhi nilai perusahaan perbankan yang terdaftar di BEI priode 2014-2017. Penelitian (Indahningrum, 2020) menunjukan bahwa frekuensi rapat dewan direksi berpengaruh positif terhadap frim value melalui corporate environmental disclosure. Penelitian (Yadhi George Makarios Sagala, 2019) menunjukan bahwa frekuensi rapat dewan berpengaruh positif terhadap kinerja perusahaan. Hasil penelitian (AlDaoud et al., 2016) menunjukan terdapat hubungan positif antara frekuensi rapat dewan direksi terhadap kinerja perusahaan. Hasil penelitian ini sejalan dengan penelitian (EVIYANAH, 2018) yang menunjukan bahwa frekuensi rapat dewan direksi berpengaruh positif dan signifikan terhadap kinerja keuangan perusahaan. Dari penelitian terdahulu, dalam penelitian ini di ambil hipotesis:

H4: frekuensi rapat dewan direksi berpengeruh positif dan signifikan terhadap kinerja keuangan perusahaan sector trade, service and investmen.

\section{METODE}

Penelitian ini merupakan penelitian kuantitatif karena fenomena yang di teliti bersifat numerik. Teknik pwngumpulan data yang di gunakan untuk memperoleh data penelitian adalah dokumentasi, yaitu cara cara pengumpulan data dengan melihat dan mengunakan laporan-laporan, yang terdapat di IDX berupa laoran keuangan tahunan priode 2014-2018 yaitu www.idx.co.id. Populasi peneiltian ini adalah seluruh perusahaan sector trade, service and investmen yang terdaftar di IDX yaitu 177 perusahaan dengan sempel sebanyak 23 perusahaan yang dipilih menggunkan teknik purposive sampling.

\section{HASIL DAN PEMBAHASAN}

\section{Analisis Statistik Deskriptif}

Tabel 1. Descriptive Statistics

\begin{tabular}{lrrrrrr}
\hline & $\mathrm{N}$ & Minimum & \multicolumn{1}{c}{ Maximum } & \multicolumn{2}{c}{ Mean } & \multicolumn{1}{c}{ Std. Deviation } \\
\cline { 2 - 7 } & Statistic & Statistic & Statistic & Statistic & \multicolumn{1}{c}{ Std. Error } & \multicolumn{1}{c}{ Statistic } \\
\hline PDKI & 115 & 3.00 & 6.00 & 4.0696 & .08443 & .90536 \\
\hline KA & 115 & 2.00 & 4.00 & 3.0696 & .02954 & .31683 \\
\hline UDD & 115 & 2.00 & 9.00 & 5.3652 & .14735 & 1.58020 \\
\hline FRDD & 115 & 2.00 & 72.00 & 19.3217 & 1.35755 & 14.55814 \\
\hline
\end{tabular}




\begin{tabular}{lrrrrrr}
\hline & $\mathrm{N}$ & Minimum & \multicolumn{1}{c}{ Maximum } & \multicolumn{2}{c}{ Mean } & Std. Deviation \\
\cline { 2 - 7 } & Statistic & Statistic & Statistic & Statistic & Std. Error & Statistic \\
\hline $\begin{array}{l}\text { Kinerja Keuangan } \\
\text { Perusahaan }\end{array}$ & 115 & 1.00 & 98.00 & 34.9565 & 2.63389 & 28.24529 \\
\hline Valid N (listwise) & 115 & & & & & \\
\hline \multicolumn{1}{c}{ Sumber: pengolahan data SPSS21 } & & & & \\
\end{tabular}

Hasil analisis deskriptif yang diperoleh melui tabel 2:

Proporsi Dewan Komisaris Independen (PDKI), dengan nilai mean sebesar 4,0696 dengan deviasi standart 0,90536 serta nilai minimum sebesar 3,00 dan nilao maksimum sebesar6,00. Komite Audit (KA), memiliki nilai mean sebesar 3,0696, nilai deviasi standart sebesar 0,31683, nilai minimum sebesar 2,00 dan nilai maksimum sebesar 4,00. 3. Ukuran Dewan Direksi (UDD), memiliki nilai mean sebesar 5,3652 , nilai standart deviasi sebesar 1,58020, nilai minimum sebesar 2,00 dan nilai maksimum sebesar 9,00. Frekuensi Rapat Dewan Direksi (FRDD), memiliki nilaimean sebesar 19,3217, nilai deviasi standart sebesar 14,55814, nilai minimum sebesar 2,00 dan nilai maksimum sebesar 72,00. Kinerja Keuangan Perusahaan, memiliki nilai mean sebesar 34,9565, nilai deviasi standart sebesar 28,24529, nilai minimum sebesar 1,00 dan nilai maksimum sebesar 98,00.

\section{Analisis Asumsi Klasik}

\section{Uji Normalitas}

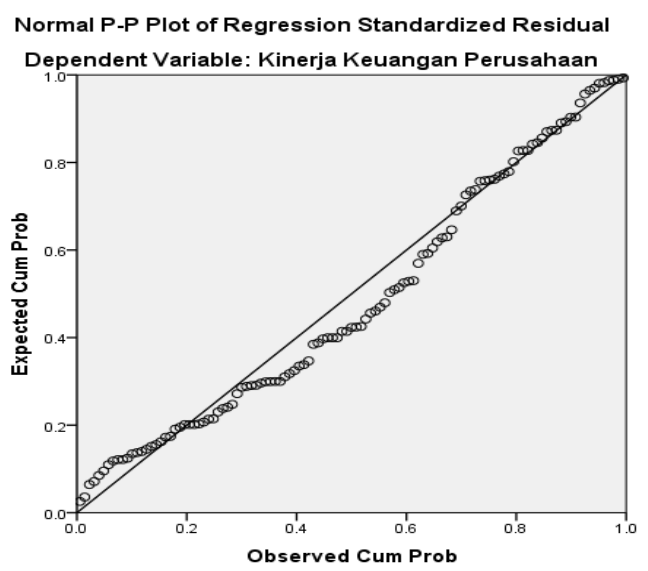

Gambar 2. Normalitas Probability plot Sumber: Data Output SPSS21

Gambar normal P-P Plot menunjukan gambar pola data yang baik, dimana dapat dilihat data menyebar disekitar garis diagonal dan mengikuti arah garis diagonal, hal ini menunjukan pola distribusi normal dan memenuhi asumsi normalitas.

\section{Uji Multikolinearitas}

Tabel 2. Hasil Uji Multikolinearitas

\begin{tabular}{lcc}
\hline \multirow{2}{*}{ Model } & \multicolumn{2}{c}{ Collinearity Statistics } \\
\cline { 2 - 3 }$($ Constant $)$ & \multicolumn{2}{c}{ Tolerance } \\
\hline PDKI & .776 & VIF \\
\hline KA & .933 & 1.288 \\
\hline UDD & .708 & 1.072 \\
\hline FRDD & .952 & 1.412 \\
\hline a. Dependent Variable: Kinerja Keuangan Perusahaan \\
\hline \multicolumn{2}{c}{ Sumber: data output SPSS21 }
\end{tabular}


Hasil menunjukan nilai tolerance seluruh variabel bebas lebih dari 0,10 begitupun nilai VIF seluruh variabel bebas kurang dari 10. Oleh karena itu dapat di asumsikan tidak ada multikolinearitas antar variabel dalam regresi.

\section{Uji Heterokedastisitas}

Scatterplot

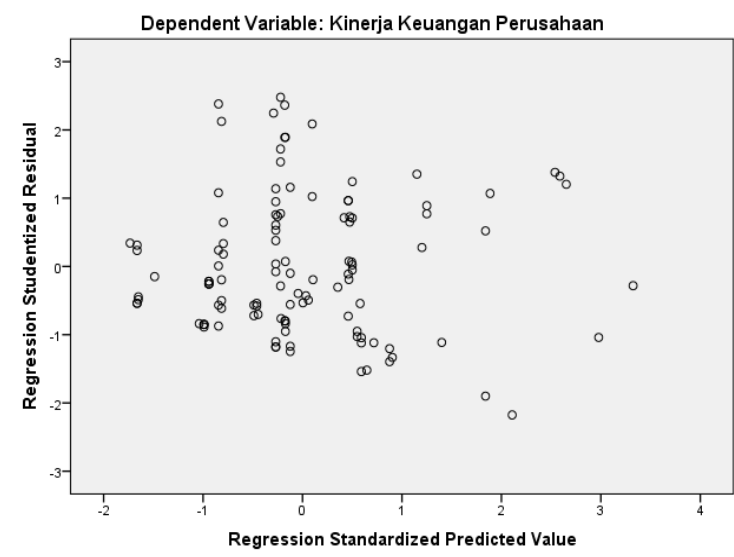

Gambar 2. Grafik Scatterplot Sumber: data output SPSS21

Berdasarkan grafik scatterplot yang dihasilkan terlihat hamper semua titik menyebar secara acak, tidak membentuk pola tertentu yang jelas serta terseber diatas maupun dibawah angka 0 dan Y. hal ini berarti tidak terjadi heterokedastisitas pada model regresi layak dipakai untuk mengetahui kinerja keuangan perusahaan berdasar dari variabel independen.

\section{Analisis Regresi Berganda}

Tabel 4. Uji Regresi Berganda

Coefficients $^{\mathrm{a}}$

\begin{tabular}{|c|c|c|c|c|c|c|}
\hline & \multirow[t]{2}{*}{ Model } & \multicolumn{2}{|c|}{ Unstandardized Coefficients } & \multirow{2}{*}{$\begin{array}{c}\begin{array}{c}\text { Standardized } \\
\text { Coefficients }\end{array} \\
\text { Beta } \\
\end{array}$} & \multirow[t]{2}{*}{$\mathrm{t}$} & \multirow[t]{2}{*}{ Sig. } \\
\hline & & $\mathrm{B}$ & Std. Error & & & \\
\hline \multirow{5}{*}{1} & (Constant) & -11.068 & 28.763 & & -.385 & .701 \\
\hline & PDKI & -7.282 & 3.118 & -.233 & -2.335 & .021 \\
\hline & KA & 22.762 & 8.130 & .255 & 2.800 & .006 \\
\hline & UDD & .527 & 1.870 & .029 & .282 & .779 \\
\hline & FRDD & .153 & .175 & .079 & .876 & .383 \\
\hline
\end{tabular}

Sumber: Data Output SPSS21

Berdasarkan tabel di atas diperoleh persamaan regresi linier berganda sebagai berikut:

$\mathrm{KKP}=-11,068-7,282 \mathrm{PDKI}+22,762 \mathrm{KA}+$ 0,52 UDD + 0,153 FRDD

Uji regresi linier berganda dikolompokkan menjadi pengujian parsial, uji kelayakan model (uji good of fit ) dan pengujian keterikatan variabel dependen dengan independen. Adapun hasil pengujian csebagai berikut:

\section{Uji good of fit (uji kelayakan model)}

Tabel 5. Uji Kelayakan Model

ANOVA ${ }^{a}$

\begin{tabular}{ccccccc}
\hline & Model & Sum of Squares & df & Mean Square & F & Sig. \\
\hline \multirow{2}{*}{1} & Regression & 13354.487 & 4 & 3338.622 & 4.733 & $.001^{\text {b }}$ \\
\cline { 2 - 7 } & Residual & 77594.296 & 110 & 705.403 & & \\
\cline { 2 - 7 } & Total & 90948.783 & 114 & & & \\
\hline
\end{tabular}

a. Dependent Variable: Kinerja Keuangan Perusahaan

b. Predictors: (Constant), FRDD, PDKI, KA, UDD

Sumber: data Output SPSS21 
Berdasarkan hasil uji statistik $\mathrm{F}$ menunjukan $\mathrm{F}$ hitung sebesar 4,733 dengan tingkat signifikan sebesar 0,001 karena probabilitas signifikan jauh lebi kecil dari 0,05 $(\alpha=5 \%)$, sehingga kesimpulan model yang digunakan dalam penelitian ini layak digunakan pada penelitian pengaruh corporate governance terhadap kinerja keangan perusahaan sector trade service and investmen yang terdaftar di IDX priode 2014-2018.

\section{Uji Koefisien Determinasi $\left(R^{2}\right)$}

Tabel 6. Koefisien Determinasi

Model Summary ${ }^{b}$

\begin{tabular}{cccccc}
\hline Model & $\mathrm{R}$ & $\mathrm{R}$ Square & $\begin{array}{c}\text { Adjusted R } \\
\text { Square }\end{array}$ & $\begin{array}{c}\text { Std. Error of the } \\
\text { Estimate }\end{array}$ & Durbin-Watson \\
\hline 1 & $.383^{\mathrm{a}}$ & .147 & .116 & 26.55942 & .936 \\
\hline
\end{tabular}

a. Predictors: (Constant), FRDD, PDKI, KA, UDD

b. Dependent Variable: Kinerja Keuangan Perusahaan

Sumber: data output SPSS21

Pada tabel diatas, hasil analisis dapat dilihat $\mathrm{R}$ Square sebesar 0,147 menunjukan bahwa korelasi atau keeratan hubungan PDKI,KA,UDD, dan FRDD sebesar 14,7\%. Nilai R Square sebesar 0,116 mengindikasikan bahwa variasi PDKI,KA,UDD, dan FRDD menjelaskan variasi terhadap kinerja keuangan perusahaan sebesar $11,6 \%$ sedangkan sisanya $88,4 \%$ dijelaskan oleh factor-faktor lain diluar variabel yang belom diteliti.

\section{Pengujian Signifikansi Secara Parsial (Uji t)}

\begin{tabular}{|c|c|c|c|c|c|c|}
\hline & \multirow[t]{2}{*}{ Model } & \multicolumn{2}{|c|}{ Unstandardized Coefficients } & \multirow{2}{*}{$\begin{array}{c}\text { Standardized } \\
\text { Coefficients } \\
\text { Beta } \\
\end{array}$} & \multirow[t]{2}{*}{$\mathrm{t}$} & \multirow[t]{2}{*}{ Sig. } \\
\hline & & $\mathrm{B}$ & Std. Error & & & \\
\hline \multirow{5}{*}{1} & (Constant) & -11.068 & 28.763 & & $\begin{array}{c}- \\
.385\end{array}$ & .701 \\
\hline & PDKI & -7.282 & 3.118 & -.233 & $\begin{array}{c}- \\
2.335\end{array}$ & .021 \\
\hline & KA & 22.762 & 8.130 & .255 & 2.800 & .006 \\
\hline & UDD & .527 & 1.870 & .029 & .282 & .779 \\
\hline & FRDD & .153 & .175 & .079 & .876 & .383 \\
\hline
\end{tabular}

a. Dependent Variable: Kinerja Keuangan Perusahaan

Sumber:data output SPSS21

Variabel PDKI secara parsial memiliki thitung sebesar -2,335 ( minus merupakan arah hubungan berlawanan ) dan nilai $t$ tabel sebesar 1,98177, sehingga dapat dibandingkan bahwa t hitung $>t$ tabel atau $2,335>1,98177$, dengan nilai signifikansi 0,021<0,05. Dari hasil tersebut dapat disimpulkan Ho dan H1 diterima, variabel proporsi dewan komisaris independen (PDKI) berpengaruh signifikan negative terhadap kinerja keungan perusahaan. Dalam penelitian (Mulyadi, 2016) dan (Bashir et al., 2020) menemukan pengaruh antara proporsi dewan komisaris independen berpengaruh terhadap kinerja keuangan perusahaan. Hasil ini menunjukan semakin besar dewan komisaris independen akan berdampak terhadap menurunnya kinerja keuangan perusahaan. Hasil ini konsisten dengan penelitian (Yunina \& Nisa, 2019) yang menyatakan bahwa setiap peningkatan jumlah anggota dewan komisaris independen akan berdampak terhadap menurunnya kinerja bank syariah.

Variabel komite audit secara parsial memiliki t hitung sebesar 2,800 dan nilai $t$ tabel sebesar 1,98177 sehingga dapat dibandingkan bahwa t hitung $>t$ tabel atau 2,800>1,98177, dengan nilai signifikansi 0,006<0,05. Dari hasil tersebut disimpulkan Ho ditolak dan $\mathrm{H} 2$ diterima yang artinya secara parsial komite audit (KA) berpengaruh positif dan signifikan terhadp kinerja keuangan perusahaan. Hasil ini konsisten dengan penelitian (Widianingsih, 2018), (Agatha et al., 2020) dan (Nurhidayah, 2020) menunjukan bahwa komite audit memiliki pengaruh positif dan signifikan terhadap kinerja keuangan perusahaan. Dengan demikian hasil penelitia ini bahwa banyaknya anggota komite audit akan 
memberikan perlindungan kepada para shareholder dan semakin optimal fungsi pengawasan terhadap proses akuntansi serta keuangan. Hal ini sesuai dengan fungsi yang di emban oleh komite audit, yakni membantu dewan komisaris dalam menjalankan kajian ats integritas laporan keuangan, manajemen resiko dan pengendalian internal (Yunina \& Nisa, 2019)

Variabel UDD secara parsial memiliki t hitung sebesar 0,282 dan nilai t tabel sebesar 1,98177 sehingga dapat dibandingkan bahwa $t$ hitung $<\mathrm{t}$ tabel atau $0,282<1,98177$ dengan nilai signifikan $0,779>0,05$. Dari hasil tersebut dapat disimpulkan Ho diterima dan $\mathrm{H} 3$ di tolak, yang artinya secara parsial ukuan dewan direksi tidak berpengaruh sihgnifikan terhadap kinerja keuangan perusahan. Hasl ini konsisten dengan penelitian (Hendratni, 2018), (Palaniappan, 2017) dan (Setiawan, 2016) menunjukan bahwa jumlah atau ukuran dewan direksi atau ukuran direksi tidak berpengaruh signifikan terhadap kinerja keuangan perushaan. Dengan demikian hasil ini menunjukan bahwa jumlah anggota dewan direksi tidak memberikan pengaruh yang signifikan terhadap peningkatan kinerja keuangan perusahaan sector trade, service an investmen priode 2014-2018. Hal ini menunjukan bahwa ukuran dewan direksi berpengaruh terhadap peningkatan peningkatan kinerja keuangan perusahaan.

Variabel FRDD secara parsial memiliki t hitung sebesar 0,876 dan nilai t tabel sebesar 1,98177 sehingga dapat dibandingkan bahwa $t$ hitung <t tabel atau 0,876<1,98177 dengan nilai signifikan $0,383<0,05$. Dari dari hasil tersebut dapat disimpulkan Ho diterima dan $\mathrm{H} 4$ di tolak, yang artinya secara parsial frekuensi rapat dewan direksi tidak berpengaruh terhadap kinerja keuangan perushaan sector trade, service and investment priode 2014-2018. Hasil ini konsisten dengan penelitian (Hanh et al., 2018), (EVIYANAH, 2018) dan (Palaniappan, 2017) menunjukan bahwa frekuensi rapat dewan direksi tidak berpengaruh signifikan terhadap kinerja keuangan perushaan. Dengan demikian hasil penelitian memungkinkan bahwa setiap penaikan jumlah rapat dewan direksi akan berdampak terhadap menurunnya kinerja keuangan perusahaan. Hasil ini menunjukan bahwa intensitas rapat dewan direksi mempengaruhi kinerja keuanagan perushaan.

\section{SIMPULAN}

Hasil penelitian menunjukan bahwa variabel proporsi dewan komisaris independen berpengaruh negative dan signifikan terhadap kinerja keungan perusahaan sector trade, service and investmen priode 2014-2018. Jumlah komisaris independen yang cukup dapat mengawasi prilaku manajemen dan pengelolaan perusahaan. Variabel komite audit berpengaruh positif dan signifikan terhadap kinerja keuangan perusahaan sector trade, service and investmen priode 2014-2018. Hasil penelitian ini menunjukan bahwa jumlah anggota komite audit dapat mempengaruhi meningkatnya kinerja keuang an perusahaan. Sedangkan variabel ukuran dewan direksi dan frekuensi rapat dewan direksi tidak berpengaruh signifikan terhadap kinerja keuangan perusahaan sector trade, service and investmen priode 2014-2018. Dengan demikian menunjukan bahwa ukuran dewan direksi dan frekuensi rapat dewan direksi tidak mempengaruhi kinerja keuangan perusahaan.

Penelitian selanjutnya diharapkan menambahkan variabel lain diluar variabel ini, missal nilai perusahaan, kepemilikan institusional, kepemilikan manajerial, dan beberapa variabel lainnya sehingga dapat mempengaruhi kinerja keungan perusahaan. Serta memperluas obyek penelitian seperti pada sector finance, atau seluruh perusahaan yang terdaftar di IDX serta memperpanjang periode. Hendaknya mempertimbangkan untuk menggunakan metode pengukuran kinerja keuangan perusahaan selain ROA (Return On Asset) karena hanya mampu menilai dengan data-data yang ada didalam laporan keuangan sehingga beberapa penilaian menggunakan metode tersebut masih terdapat hasil yang tidak konsisten. Sehingga peneliti selanjutnya bisa menggunakan metode lain yang memungkinkan lebih sesuai untuk menjelaskan kinerja keuangan perusahaan seperti Tonbin's $Q$.

\section{DAFTAR PUSTAKA}

Abdulazeez DA, N. and M. A. (2016). Corporate Governance and Financial Performance of Listed Deposit Money Banks in Nigeria. Journal of Accounting \& Marketing, 05(01), 1-6. 
https://doi.org/10.4172/2168-9601.1000153

Agatha, B. R., Nurlaela, S., \& Samrotun, Y. C. (2020). Managerial, Institutional Ownership, Independent Board Of Commissioners, Audit Committee And Food And Beverage Financial Performance. E-Jurnal Akuntansi Universitas Udayana, 30 No.7, 1811-1826.

Al-Daoud, K. I., Saidin, S. Z., \& Abidin, S. (2016). Board meeting and firm performance: Evidence from the Amman stock exchange. Corporate Board: Role, Duties and Composition, 12(2), 6-11. https://doi.org/10.22495/cbv12i2art1

Atmaja, Y. W., Riswan, \& Tohir. (2015). Analisis Pengaruh Good Corporate Governance, Ukuran Perusaahaan, dan Leverage Perusahaan terhadap Kinerja Keuangan Sektor Perbankan(Studi pada Perusahaan Perbankan yang Terdaftar di Bursa Efek Indonesia (BEI) Tahun 2009-2013). Journal \& Proceeding FEB Unsoed, 21(1), 1-15. http://jos.unsoed.ac.id/index.php/ performance/article/view/877/658

Azis, A., \& Hartono, U. (2017). Pengaruh Good Corporate Governance, Struktur Modal, Dan Leverage Terhadap Kinerja Keuangan Perusahaan Pada Sektor Pertambangan Yang Terdaftar Di Bursa Efek Indonesia Tahun 2011-2015. Jurnal Lmu Manajemen, 5(3), 1-13.

Bashir, Z., Bhatti, G. A., \& Javed, A. (2020). Corporate governance and capital structure as driving force for financial performance: Evidence from non-financial listed companies in Pakistan. Business Review, 15(1).

BUMN, M. N. B. (2011). Peraturan Menteri Negara Badan Usaha Milik Negara (BUMN) No: PER01/MBU/2011. (Per-01/Mbu 2011), http://jdih.bumn.go.id/baca/PER-01/MBU/2011.pdf.

Cabrera Marino, K. M. (2017). Инновационные подходы к обеспечению качества в здравоохраненииNo Title. Вестник Росздравнадзора, 6, 5-9.

Dhea Gitami Fintreswari, F. S. (2017). Pengaruh Kinerja Keuangan, Good Corporate Governance Terhadap Nilai Perusahaan Food and Beverage. Jurnal Manajemen Dan Kewirausahaan, 14(2), 203-216. https://doi.org/10.9744/jmk.14.2.118-127

Eksandy, A. (2018). Pengaruh Good Corporate Governance Terhadap Kinerja Keuangan Pada Perbankan Syari'Ah Indonesia. Jurnal Akuntansi: Kajian Ilmiah Akuntansi (JAK), 5(1), 1. https://doi.org/10.30656/jak.v5i1.498

EVIYANAH, I. (2018). ANALISIS PENGARUH CORPORATE GOVERNANCE TERHADAP KINERJA KEUANGAN PADA PERUSAHAAN YANG TERDAFTAR DI INDEX SAHAM SYARIAH INDONESIA ( ISSI ) PERIODE 2012-2016 YANG TERDAFTAR DI INDEX SAHAM SYARIAH.

Ginting, R. B., Samosir, C. P., Priwendamai, F., \& Ginting, W. Va. (2020). Faktor- Faktor Yang Mempengaruhi Kebijakan Dividen Pada Sektor Trade, Service, And Investment Terdaftar Di Bursa Efek Indonesia Periode 2014-2018. Owner, 4(1), 303. https://doi.org/10.33395/owner.v4i1.225

Governance, K. N. G. C. (2016). Pedoman Pembentukan Komite Audit yang Efektif. Knee Surgery, Sports Traumatology, Arthroscopy, 24(3), 707-711. https://doi.org/10.1007/s00167-015-3516-9

Hanh, L. T. M., Ting, I. W. K., Kweh, Q. L., \& Hoanh, L. T. H. (2018). Board meeting frequency and financial performance: A case of listed firms in Vietnam. International Journal of Business and Society, 19(2), 464-472.

Hendratni, T. W. et al. (2018). Kinerja Keuangan Sektor Perbankan Yang Terdaftar Di Bei Tahun 20122016. Jurnal Riset Manajemen Dan Bisnis (JRMB) Fakultas Ekonomi UNIAT, 3(1), 37-52.

Hong, N. Y., San, O. T., Tunku, U., \& Rahman, A. (2016). Assessing the relationship among corporate governance, sustainability disclosure and financial performance. Asia-Pacific Management Accounting Journal, 11(2), 129-146.

Indahningrum, R. putri. (2020). CORPORATE GOVERNANCE, CORPORATE ENVIRONMENTAL DISCLOSURE DAN FIRM VALUE. 2507(1), 1-9.

Jensen, M. C. (1993). the Modern Industrial Revolution, Exit, and the Failure of Internal Control Systems. Journal of Applied Corporate Finance, 6(4), 4-23. https://doi.org/10.1111/j.17456622.1994.tb00244.x

Kusnadi, M. D. (2018). Pengaruh Dimensi Good Corporate Governance Terhadap Kinerja Keuangan (Studi pada Badan Usaha Milik Negara yang Terdaftar di Bursa Efek Indonesia). Jurnal Administrasi Bisnis (JAB), 7(2), 1-19.

Mohammed, H. D. (2020). Corporate Governance and Financial Performance of Quoted Companies in Nigeria. European Journal of Business and Management, 12(6), 31-40. 
https://doi.org/10.7176/ejbm/12-6-04

Muhammad Rizky Afinurzaid, S. B. H. (2019). Pengaruh Good Corporate Governance, Dan Karakteristik Perusahaan Terhadap Nilai Perusahaan. Jurnal Bisnis Dan Akuntansi, 20(1), 21-32. https://doi.org/10.34208/jba.v20i1.404

Mulyadi, R. (2016). PENGARUH CORPORATE GOVERNANCE TERHADAP KINERJA KEUANGAN. Routledge Handbook of Japanese Business and Management, 3(1), 59-74. https://doi.org/10.4324/9781315832661

Nurhidayah, V. (2020). Pengaruh Good Corporate Governance Terhadap Kinerja Keuangan Pada Perbankan Di Bei. Prisma (Platform Riset Mahasiswa Akuntansi) Volume 01 Nomor 02 Tahun 2020 (Hal: 132-142, 01, 132-142.

Palaniappan, G. (2017). Determinants of corporate financial performance relating to board characteristics of corporate governance in Indian manufacturing industry: An empirical study. European Journal of Management and Business Economics, 26(1), 67-85. https://doi.org/10.1108/EJMBE-07-2017-005

Perusahaan, U.-U. N. 8 P. 1 ayat (1) T. 1997 tentang dokumen. (1997). UU Dokumen Perusahaan. Undang-Undang No. 8 Pasal 1 Ayat (1) Tahun 1997 Tentang Dokumen Perusahaan.

Prayanthi, I., \& Laurens, C. N. (2020). Pengaruh Dewan Direksi, Komisaris Independen, Dan Komite Audit Terhadap Kinerja Keuangan Pada Sektor Makanan Dan Minuman. Klabat Journal of Management, I(1), 66. https://doi.org/10.31154/kjm.v1i1.450.66-89

PUTRI, R. M. (2018). PENGARUH MEKANISME CORPORATE GOVERNANCE TERHADAP NILAI PERUSAHAAN PERBANKAN Oleh: RAUDHATUL MARDHIAH PUTRI Pembimbing: Diajukan Untuk Memenuhi Salah Satu dari Syarat-Syarat Guna Memperoleh Gelar Sarjana Ekonomi PADANG.

Saifi, M. (2019). Pengaruh Corporate Governance Dan Struktur Kepemilikan Terhadap Kinerja Keuangan Perusahaan. Profit, 13(02), 1-11. https://doi.org/10.21776/ub.profit.2019.013.02.1

Salsabila Sarafina, M. S. (2017). PENGARUH GOOD CORPORATE GOVERNANCE TERHADAP KINERJA KEUANGAN DAN EFEKNYA TERHADAP NILAI PERUSAHAAN (Studi Pada Badan Usaha Milik Negara yang Terdaftar di Bursa Efek Indonesia Periode 2012-2014). Jurnal Administrasi Bisnis S1 Universitas Brawijaya, 33(1), 146-153.

Setiawan, A. (2016). Pengaruh Corporate Governance Terhadap Kinerja Keuangan Perusahaan. Jurnal SIKAP (Sistem Informasi, Keuangan, Auditing Dan Perpajakan), $1(1), 1$. https://doi.org/10.32897/sikap.v1i1.41

Sigalingging, Y. N., \& Dewi, A. S. (2019). PENGARUH KEBIJAKAN DIVIDEN DAN UKURAN PERUSAHAAN TERHADAP LEVERAGE PERUSAHAAN DENGAN INVESTMENT OPPORTUNITY SET (IOS) SEBAGAI VARIABEL MODERASI PADA SEKTOR TRADES, SERVICES \&Amp; INVESTMENT YANG TERDAFTAR DI BEI. 1-23. https://doi.org/10.31227/osf.io/6sa8n

Togatorop, N. S., Siregar, M. K. S., Tanjung, M. A., \& Hulu, K. (2019). Pengaruh Leverage (DER), Return On Assets (ROA), Rasio Lancar (CR), Terhadap Harga Saham Pada Sektor Trade, Service \& Investment Di Bursa Efek Indonesia Periode 2015-2018. Jurnal Global Manajemen, 8, 1-11.

U. B. Azubike, J., Joseph Ugochukwu, M., \& Ikechichukwu Innocent, O. (2015). Impact of Corporate Board Meetings on Financial Performance: Evidence from Selected Listed Companies in Nigeria. International Journal of Economics and Finance, 7(12), 268. https://doi.org/10.5539/ijef.v7n12p268

Widianingsih, D. (2018). Kepemilikan Manajerial, Kepemilikan Institusional, Komisaris Independen, serta Komite Audit pada Nilai Perusahaan dengan Pengungkapan CSR sebagai Variabel Moderating dan Firm Size sebagai Variabel Kontrol. Jurnal Akuntansi Dan Pajak, 19(1), 38. https://doi.org/10.29040/jap.v19i1.196

Yadhi George Makarios Sagala, P. B. H. (2019). Pengaruh keterlibatan dewan direksi terhadap kinerja perusahaan. Diponegoro Journal of Accounting, 8(3), 1-11.

Yunina, F., \& Nisa, N. (2019). Pengaruh Good Corpoate Governance Terhadap Kinerja Keuangan Bank Syariah Tahun 2015-2017. Jurnal Akuntansi, 10(1), 45-56. 